staffing of theological colleges, worship, post-graduate studies, literature, and language are dealt with in brief sections. The concluding chapter offers specific recommendations for the improvement of existing institutions and methods and for the establishment, in South Africa, of a standing committee on theological training, representing the various Churches and convened to undertake specific tasks. Special problems and needs in the Rhodesias and Nyasaland, and suggestions for the uniting of small theological colleges, conclude this section. The chief problems dealt with, and the improvements to be aimed at are summarized on pp. 60, 6x. Publication of the fourth report in the series, by Professor Bengt Sundkler, is expected early in the current year.

\title{
Le Musée historique d'Abomey
}

LE Musée historique d'Abomey (Dahomey) a été aménagé dans l'ancien palais des rois Guézo (1 818-58) et Glèlè (18 5 8-89). Sa gestion a été confiée depuis I945 à l'Institut Français d'Afrique Noire (centre de Dahomey). Il comprend actuellement trois grandes salles, situées dans les anciennes cours royales, où l'on trouve réunies de nombreuses collections de troncs, de statuettes, de bijoux etc., ayant appartenu aux souverains dahoméens. Il a reçu pendant l'année 1954 la visite de 24.700 personnes dont 656 Européens. Le nombre des visiteurs pendant l'année I953 s'était élevé à 18.500 . Ces chiffres prouvent bien l'intétêt croissant qu'Européens comme Africains portent aux vieilles civilisations de l'Afrique.

\section{Le Musée historique de l'A.O.F. (Dakar)}

LE. 4 juin r 954 a été inauguré dans l'âle de Gorée, par M. le Haut Commissaire CornutGentille, le Musée historique de l'A.O.F. M. A. Ly, directeur du Musée, présenta dans son allocution le but poursuivi: créer un centre de rayonnement de la culture et aider les Africains à se situer dans le milieu où ils vivent. Le Musée - le premier que compte la ville de Dakar - a été aménagé dans une maison du XVIIIe siècle juste en face de la Maison des esclaves. Le Musée comprend douze salles d'exposition groupées en deux corps de bâtiments de chaque côté d'une cour. Une salle est consacrée au milieu naturel, et une seconde présente le milieu humain - des cartes ethniques et démographiques, des photographies et des objets d'art et d'artisanat nègres et sahariens permettent de se faire une idée de la complexité du peuplement humain et des problèmes ethniques de l'ouest africain. Trois salles sont consacrées à la préhistoire et à la protohistoire; d'autres salles présentent les grands empires noirs (du VIIIe au XVIIe siècle), l'installation des Européens sur les côtes, les organisations politiques de l'intérieur, le mécanisme de la traite négrière; les deux dernières salles couvrent la période de la fin du XVIIIe à la fin du XIXe siècle, et dans la grande salle sud ont été groupés des documents postérieurs à la première guerre mondiale, destinés à évoquer l'évolution de l'Afrique occidentale moderne: urbanisme, industrialisation, aspects de Dakar aujourd'hui etc.

Ce Musée constitue le premier maillon d'une chaîne qui comprendra aussi le Musée de la Mer, en préparation à Gorée, et un Musée d'ethnographie et d'histoire naturelle à Dakar.

\section{Conseil Coutumier de Brazzaville}

LE Conseil Coutumier de Brazzaville a été fondé en IgSI par l'initiative de M. Maurice Kwamm, M. Prosper Mahoukou, l'Abbé Fulbert et un groupe d'Africains de Brazzaville. Cet organisme s'est donné pour tâche de fixer par écrit les Coutumes du Moyen-Congo, à partir desquelles pourront être étudiées des nouvelles règles plus conformes aux exigences de la vie moderne. Dans les agglomérations africaines de Brazzaville, où se côtoient presque 
toutes les races d'A.É.F., les tribunaux coutumiers sont souvent appelés à régler des litiges qui opposent des personnes régies par des coutumes parfois peu connues de leurs assesseurs. C'est pourquoi le Conseil Coutumier a essayé de donner un instrument de travail aux tribuns indigènes de Brazzaville en leur permettant de se référer à des coutumes écrites en ce qui concerne les principales races du Moyen-Congo. On espère que cette initiative du Conseil Coutumier s'étendra dans les autres territoires de la Fedération et que des filiales seront créées à d'autres centres. Le Conseil Coutumier doit en outre servir d'organisme central consultatif pour les juridictions indigènes. Les cas pour lesquels la coutume n'est pas nette ou ceux dans lesquels il y a opposition de coutumes lui seront soumis.

Un fascicule, édité par le Conseil Coutumier, contient un exposé des coutumes du MoyenCongo, publié sous la responsabilité des notables africains de Poto-poto et de Bacongo, dont la liste est imprimée.

Les sections du fascicule comprennent des chapitres traitant de la famille: les droits et les devoirs du chef de famille; le mariage; les fiançailles; régime patriarcal, régime matriarcal; la dot; situation des époux; dissolution du mariage. Un chapitre traite des coutumes sangha - sangha, bakouele et djem - celles-ci étant assez différentes des autres du MoyenCongo. Deux chapitres sont consacrés aux coutumes concernant la naissance et le choix de nom. En conclusion, le Conseil Coutumier formule quelques recommandations concernant le divorce.

\section{Interafrican Soils Conference}

THE Interafrican Soils Conference held at Léopoldville in 1954 (see Africa, Oct. 1954, p. 272) reviewed the progress made by the permanent organizations founded in 1948 (Bureau Interafricain des sols, Paris; Service pédologique africain, Yangambi, and three regional committees). In approving the work done by these organizations, under the auspices of C.C.T.A., the conference took special note of the results achieved in the fields of study, cartography, soil conservation and utilization. It recommended that details of the methods of soil analysis used by the member countries should be communicated to S.P.A. at Yangambi, and emphasized the importance of studying the composition, origins, and formation of soils, and the bearing of these studies on measures for conserving soil fertility. Considerable discussion took place on the project of preparing a series of maps of soils in different regions, and on the need for a standardization of terminology, nomenclature, and methods of cartography. Reports were presented and discussed on means of conserving soils, maintaining fertility and preventing deterioration. These reports revealed that substantial progress had been made in a number of territories in preventing erosion and sterilization, but the conference agreed that additional measures were necessary, particularly in the direction of educating rural populations and arousing their interest. Overstocking was also one of the problems discussed. The need for greater knowledge of, and better co-ordination of existing information relating to, the different systems of agriculture, was emphasized. A particular point was made of the importance of testing and supplementing laboratory methods, especially as regards fertilizers-both animal and mineral, by a thorough knowledge of the different soils and plants of Africa.

\section{The Killie Campbell Africana Collection}

SCHOLARS and students visiting or working in South Africa should miss no opportunity, when in Durban, of seeing Miss Killie Campbell's magnificent collection of Africana. At present kept in the old family house of the Cape Dutch style--220 Marriott Road, Durban (given to the city of Durban by Mr. William Campbell)-it is eventually intended to transfer 